\title{
Effects of Oil Rent on Economic Development in the Republic of Congo
}

\author{
Cyriaque Mbingui, Fernand Owonda, Modeste Ndoudi Diakabana \\ Faculty of Economics, Laboratory of Research and Economic and Social Studies, Marien Ngouabi University, \\ Brazzaville, Congo \\ Email: mbinguic@gmail.com, owondafernand@yahoo.fr,diakndoudi44@gmail.com
}

How to cite this paper: Mbingui, C., Owonda, F., \& Diakabana, M. N. (2021). Effects of Oil Rent on Economic Development in the Republic of Congo. Theoretical Economics Letters, 11, 587-602. https://doi.org/10.4236/tel.2021.113039

Received: May 3, 2021

Accepted: June 25, 2021

Published: June 28, 2021

Copyright $\odot 2021$ by author(s) and Scientific Research Publishing Inc. This work is licensed under the Creative Commons Attribution International License (CC BY 4.0).

http://creativecommons.org/licenses/by/4.0/ (c) (i) Open Access

\begin{abstract}
The objective of this study is to analyze the effects of oil rent on economic development in Congo over a period from 1987 to 2016. Following the estimation of the Vector Error Correction Model (VECM), the result shows that the dependence on oil rent negatively affects the development of Congo. The poor performance of growth and development in the Congo is mainly linked to the deterioration of governance and the generalization of corruption. This result allows us to formulate an economic policy implication that focuses on the sustainable management of oil resources with future generations in mind and by investing in the diversification of the country's economic activities. This would help eradicate poverty and improve the standard of living of the population.
\end{abstract}

\section{Keywords}

Oil Rent, Economic Development, Resource Curse, VECM

\section{Introduction}

The economic development of oil-producing countries in Africa is one of the major research questions for both institutions and economists. The United Nations Conference on Trade and Development (UNCTAD), held in Geneva in 2014, highlighted the extent of economic development at the global level and the issue of oil rent. The latter has remained at the center of economic development strategies.

According to Aoun (2006), the oil market, in volume and value, has remained the most important of all commodity markets. More than $60 \%$ of oil production is part of international flows, accounting for nearly three-quarter of international energy trade. The revenue generated by the oil industry remains the largest compared to other industries. 
Indeed, the contribution of oil revenues to economic development has been the subject of several studies in the economic literature. Based on the classical theory of trade, which reveals that differences in factor endowments encourage countries to specialize and export products for which they have a comparative advantage (Ohlin, 1933), the economic literature shows two groups: the pessimists and the optimists. The pessimists, who hold the so-called resource curse theory (Aoun, 2006; Ngodi, 2005a), argue that comparative advantage in natural resource exports leads to a lack of international competitiveness in other sectors (manufacturing and industry). In contrast, the optimists, advocates of the Staples theory, reveal that natural resource exports serve as an engine of the development process, both in terms of intensive and extensive growth (Mackintosh, 1967; Innis, 1967; Sid-Ahmed, 1989).

For example, Maloney $(2001,2002)$ argues that natural resources have contributed to the economic development of several major powers. The mining industry of countries with natural resources has favored the development of other economic sectors. This is the case of Chile (Davis, 1995). Norway and Indonesia have also been able to take advantage of natural resource rents to diversify their economies by developing other sectors of economic activity, with some of the highest growth rates since 1965 (van der Ploeg, 2011). In contrast, the work of Sachs and Warner (1997) showed a negative relationship between natural resources and economic growth.

However, the work of Ramey and Ramey (1995), states that the negative effects of natural resources on growth are generally due to the volatility of raw material prices. Similarly, Carbonnier (2007) believes that the negative impact of natural resources on growth should be studied on three levels, namely: 1) economic performance, 2) the risks of civil war, and 3) the functioning of institutions and governance.

The situation of African countries in terms of economic development suggests a reflection on the relevance of the relationship between oil revenues and economic development. This raises an essential question, namely: What are the effects of oil rent on economic development in Congo?

The answer to this question highlights the effects of oil rent on economic development. Because of the low level of economic diversification, this study argues that oil rent has a negative effect on economic development in Congo. This hypothesis validates the work of Aoun (2006) and Ngodi (2005b).

In general, this study is structured around five (5) points which are: 1) Introduction; 2) Oil rent and contributions to the economic development of Congo; 3) Oil rent and economic development in the literature; 4) Methodological approach and interpretation of results; 5) Conclusion and Policy implications.

\section{Oil Rent and Contributions to the Economic Development of Congo}

According to Chevalier (1975), oil rent is defined as the difference between the 
price of a unit of measurement of a natural resource, sold to consumers in the form of refined products, and the total average cost incurred to extract, transport, refine and distribute this same unit of measurement of the resource.

Forged in the logic of colonial development to meet the objectives assigned to it, the Congolese economy was gradually transformed into a cash economy, based on the production and export of natural resources in their raw state. This logic of an economy that is not truly national, but essentially an appendage of the economy of the metropolis or, today, of the world economy, was reinforced with the entry of the Congo into the oil era. The latter marked, in a way, the beginning of the gradual abandonment of traditional food and cash crop activities, thus leading to the petro-dependence of the Congolese economy (UNDP, 2012). The following Figure 1 shows the evolution of oil revenues and economic development in Congo from 1987 to 2016. It should be noted that oil revenues and economic development are respectively captured by the share of oil revenues in the economy (dependence) and the Human Development Index (HDI).

Figure 1 above shows the cross-sectional evolution of oil revenues and economic development in the Congo over the period from 1987 to 2016. Overall, the evolution of oil revenues has fluctuated over time, with recurrent and alternating oscillations, with a downward trend reaching the lowest dependence of the rent (18.17) in 2015, and restart growing up to 2016. The highest dependence of the rent (58.84) was recorded in 2000. Falls in oil prices, or disruptions in production, may explain the downward trend in recent years. In general, the evolution of the oil rent is fluctuating (Global Witness, 2017).

Economic development in the Congo, as measured by the Human Development Index (HDI), over the period 1987-2016, shows two trends. The first, from 1987 to 2003, is downward. During this period, the Republic of Congo, after 1993, was confronted with problems of political governance against the backdrop of the struggle for control over the exploitation of its natural resources, particularly oil, by various political factions. The second period, from 2004 to 2016, was bullish. Since 2005, the human development index (HDI) has improved continuously. This is only the result of the improvement in living conditions after the end of the various socio-political conflicts that the Congo has

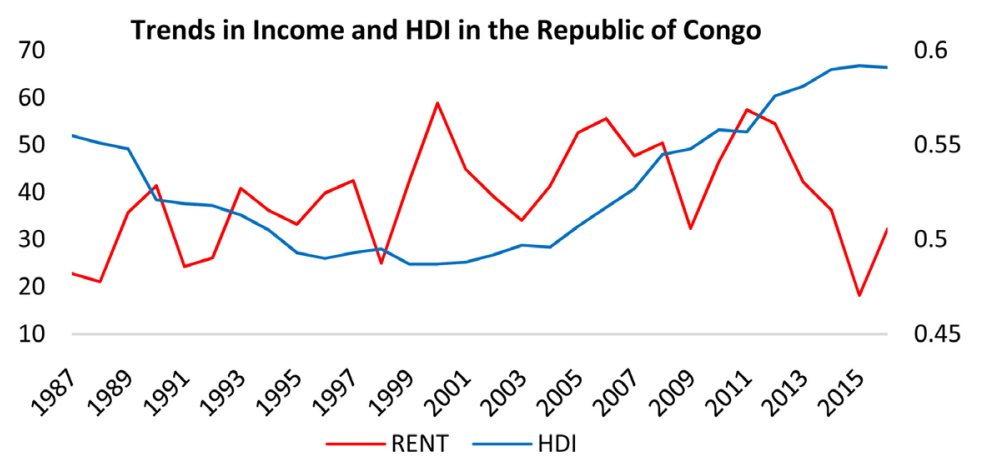

Figure 1. Evolution of the Congo's income and economic development. Source: Authors based on excel, World Bank data. 
experienced (UNDP, 2015). In sum, oil rent (dependence) and economic development are moving in opposite directions.

Figure 2 below presents the level of contribution of oil revenues to the Congolese economy through the following indicators: gross domestic product (GDP), gross fixed capital formation (GFCF), export levels (EX) and public revenue (PR).

As a result, the Congolese economy remains largely dependent on oil, which currently accounts for more than $70 \%$ of gross domestic product, $70 \%$ of gross fixed capital formation, more than $90 \%$ of exports, and more than $80 \%$ of government revenues. This dependence on oil has been unfavorable to the entire Congolese economy during periods of sluggish oil prices, such as declines in oil prices, or disruptions in production. More structurally, dependence on oil influences the performance of other sectors of activity and reinforces the weak integration of the different branches of the economy (World Bank, 2015).

\section{Oil rent and Economic Development in the Economic Literature}

This section focuses, on the one hand, on the theoretical explanation of the effects of oil rent on economic development, and on the other hand, on the empirical work that has been done on this relationship.

\subsection{Theoretical Literature}

The theoretical literature is based on two approaches that clash on one concept. On the one hand, we have the approach that admits that oil rent can hinder development and, on the other hand, the one that validates the opposite effect.

Classical trade theory emphasizes that differences in factor endowments induce countries to specialize and export certain goods and services in which they have a comparative advantage. This process promotes the more efficient allocation of resources, which in turn contributes to improved social welfare. These are the "benefits of trade".

According to Ohlin (1933), differences in resource endowments between countries are a key element of the classical theory of international trade. This

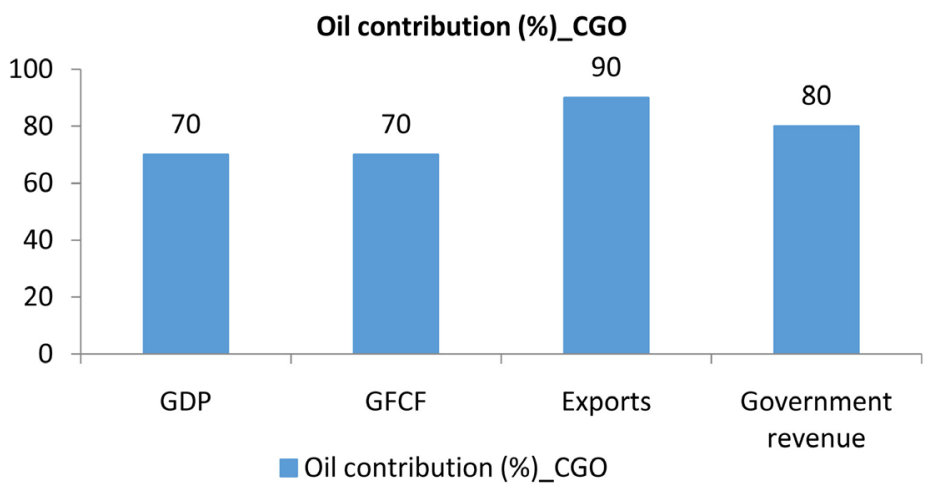

Figure 2. Contribution of oil revenues to the Congolese economy. Source: authors, World Bank (2015) data. 
theory states that, a country will export the good whose production requires the intensive use of the factor that is relatively abundant in the country and, will import the good whose production requires the intensive use of the factor that is relatively scarce. This includes cases where the natural resource is directly exported (after undergoing a small amount of processing) instead of being used as an input in the production of another product sold on the international market. For example, Leamer (1984) finds that relative abundance of oil leads to net exports of crude oil and abundance of coal and minerals leads to net exports of raw materials.

With one of the highest rates of capital per capita, the United States exports relatively labor-intensive products. This allows Leontief (1953) to question the Heckscher-Ohlin-Samuelson theory, which stipulates that countries should export goods whose production makes intensive use of the factors for which they are abundantly endowed.

Bhagwati (1958), in his theory of growth, shows that the growth in production induced by trade openness is impoverishing for countries whose exports are based on resources. For the proponents of the theory of dependence and domination (Amin, 1973; Gunder, 1970; etc.), the modalities of international trade, controlled by the developed countries, contribute to the reinforcement of the international division of labor, to the increase of international inequalities and to the dependence of Third World countries. Hirschman (1958), in his idea of unbalanced growth, has met with great interest in the resource-rich Third World countries that have gained their independence.

For his part, Hotelling (1931) shows that companies that exploit an exhaustible resource adopt a different behavior from other firms. Furthermore, Sachs and Warner (1995), in the theory of the resource curse, established a negative correlation between dependence on natural resources and economic growth. The authors explain their result by the "Dutch disease" approach, which reveals that the development of the natural resources sector is detrimental to the development of other sectors of the economy, mainly the industrial sector, because of the appreciation of the real exchange rate that it induces, considering that the slowdown in the industrial sector hampers long-term economic growth.

The theory of the curse of natural resources can be contradicted when we refer to the history of the economies of industrial powers (Canada, Australia, the United Kingdom, Norway, etc.). If the poor performance of resource-rich countries is verified despite the multiplicity of indicators, the observation remains more nuanced when we consider different periods.

For the proponents of the staples theory, the export of natural resources serves as an engine for the development process, both in terms of intensive and extensive growth. (Mackintosh, 1967; Innis, 1967; Sid-Ahmed, 1989; ...). This theory, extended in particular by Watkins (1963), applies to economies with a limited domestic market and an abundance of natural resources in relation to labor and capital. 
Thus, Wright and Czelusta (2004) believe that proponents of the natural resource curse associate natural resource abundance with comparative advantage in primary resources. A comparative advantage in natural resource exports leads to a lack of international competitiveness in other sectors (manufacturing and industrial).

\subsection{Empirical Literature}

Some empirical works, which are the object of this relationship, have been mobilized and divided according to their approaches.

In the pessimistic approach, Aoun (2006) shows that a high dependence of GDP on oil rent has a negative impact on several development indicators. Similarly, Mouhoubi (2011) argues that the processes of exploitation of natural resources generate shortfalls in development. Also, the work of Doppelhofer et al. (2004) found a negative impact of natural resource exploitation on economic growth performance. The exploitation of natural resources tends to exacerbate poverty and promote income inequality in international trade associated with economic development. Sachs and Warner (1995), found a negative impact between natural resource abundance and economic growth.

On the other hand (in the optimistic approach), some authors have found a positive relationship between natural resources and economic development. This is the case of Maloney $(2001,2002)$, who states that natural resources have often supported the economic development of several great powers, and Davis (1995), who demonstrated that the mining industry, in countries with natural resources, leads to the development of other sectors. This is the case of Chile. van der Ploeg (2011) reveals that Norway and Indonesia have taken advantage of natural resource rents to diversify their economies and develop their industrial sector, achieving high growth rates, among the best in the world since 1965 .

Auty (2001) also shows that Latin American countries with high natural resource endowments had higher GDP per capita growth rates in the 1960s than countries with low natural resource endowments.

Gylfason (2001) notes that there are trade-offs between short-term and longterm outcomes. In the short run, natural resources can bring nations substantial wealth, and in the long run, they can slow growth and lower incomes.

Similarly, Lederman and Maloney (2007) show that Sachs and Vial (2001) conclude that natural resources have a negative impact on growth only because they do not control for the variable of export diversification, the main structural characteristic of international trade associated with economic development. Taking diversification into account eliminates the negative effects of natural resource abundance on growth.

From this economic literature we find that there is a poor performance of economies dependent on primary resource exports. Oil resources not only have adverse effects on economic growth rates but also on poverty and development indicators. Countries heavily dependent on revenues from extractive industries 
face considerable challenges in eradicating poverty and raising the standard of living of the population

\section{Methodological Approach and Interpretation of Results}

This section discusses the methodology of the relationship study and presents and interprets the results.

\subsection{Methodology of the Study}

To analyze the relationship between oil rent and economic development in the Congo, the economic literature, according to Stiglitz (1974) and Solow (1974), allows us to draw inspiration from the adoc model. It states that natural resources are a factor of economic growth provided that there is perfect substitution between natural resources and technical progress. In this same vision, Georgescu-Roegen (1979) believes that there can be no development without natural resources. Consequently, the development of a country depends on the exploitation of its resource. The model borrowed from these authors makes it possible to formulate the following model:

$$
D=f(X, R)
$$

$D$ is development, $X$ is other factors and $R$ is the rent from the natural resource. In this study, development is captured by the Human Development Index (HDI) and $X$ represents the set of exogenous variables, consisting of the unemployment rate, economic growth per capita, and the infant mortality rate. Equation (1) becomes:

$$
H D I_{t}=f\left(G D P C, R E N T, U \_E M R, I M R\right)_{t}
$$

In its linearized form, the equation becomes:

$$
H D I_{t}=\alpha \ln G D P C_{t}+\beta \operatorname{lnRENT_{t}}+\gamma U_{-} E M R_{t}+\delta I M R_{t}
$$

The equation to be estimated is:

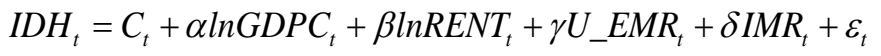

With HDI: development; $C$ : constant; RENT: oil rent; $U_{-} E M R$ : unemployment rate; GDPC: Gross Domestic Product per capita; IMR: infant mortality rate; $\alpha, \beta, \gamma$ et $\delta$ : the elasticities associated with the respective parameters; $\varepsilon_{t}:$ the error term.

\subsection{Presentation and Interpretation of Results}

This section presents the descriptive statistics and the presentation and interpretation of the results obtained.

\subsubsection{Presentation of Descriptive Statistics}

It is necessary to perform a descriptive analysis of the database of variables in this study, observed over a period of 30 years (from 1987 to 2016). This analysis is done through the characteristics of the central tendencies and dispersion such 
as the mean value of the variables, their standard deviations, etc. When there is variation around the mean, there is a deviation between each observation and the mean. The standard deviation is the set of deviations on average around the mean. In other words, the standard deviation is the average of the deviations that allows us to observe the dispersion of the data (Table 1 ).

The results of Table 1 show that the variables HDI (Human Development Index), LnRENT (logarithm of oil rent) and LnGDPC (logarithm of Gross Domestic Product per capita) show a high concentration (low standard deviations) around the mean value and on the other hand, the $U_{-} E M R$ (unemployment rate) and the $I M R$ (infant mortality rate) show a low concentration (high standard deviations) around the mean value. These low dispersions are justified by the fact that the Congo is an underdeveloped country, dependent on oil revenues, with a national wealth that is unequally distributed. The high dispersion of the unemployment rate and the infant mortality rate is justified by the fact that in Congo the level of unemployment and infant mortality is high.

\subsubsection{Presentation and Analysis of Results}

The results of the different tests performed and the model estimation are presented below.

\section{1) Stationarity analysis}

The estimation of an econometric model is conditioned by the existence of stationarity of the variables. That is, the variables must be integrated in the same order. In this study, the variables are examined using three stationarity tests: the Augmented Dickey and Fuller (ADF) test, the Philips and Perron (PP) test and the Kwiatkowski, Phillips, Schmidt, Shin (KPSS) test. The use of the latter is conditioned by the fact that the variables under study must be normally distributed, following a normal distribution. The normal distribution of the variables is apprehended from their descriptive statistics, in this case the Jarque-Bera coefficient and its associated probability, it results that certain variables of the study are stationary in level and others in first difference (see results in appendix).

\section{2) Cointegration analysis}

Table 1. Descriptive statistics.

\begin{tabular}{cccccc}
\hline & $H D I$ & LnGDPC & LnRENT & $U_{-} E M R$ & IMR \\
\hline Mean & 0.528 & 12.650 & 3.625 & 12.94 & 58.313 \\
Maximum & 0.592 & 12.805 & 4.075 & 19.300 & 76.600 \\
Minimum & 0.487 & 12.502 & 2.900 & 9.982 & 33.200 \\
Std. Dev. & 0.035 & 0.085 & 0.308 & 2.523 & 14.322 \\
Jarque-Bera & 2.677 & 1.570 & 2.085 & 3.306 & 2.673 \\
Probability & 0.262 & 0.456 & 0.352 & 0.191 & 0.2627 \\
Observations & 30 & 30 & 30 & 30 & 30 \\
\hline
\end{tabular}

Source: Authors, from Eviews7. 
The cointegration test allowed us to determine the optimal number of lags (P) taken into account in the vector autoregressive model $[\operatorname{VAR}(p)]$. We have estimated a number of autoregressive processes and selected the one that simultaneously minimizes the Akaike Information Criterion (AIC) and the Schwarz Information Criterion (SC). The optimal number taken into account in the minimization of loss of information, according to the criteria of Schwarz and Akaike, is $p=2$. At this level the two criteria present the minimal values in information loss. This result allows us to perform the Johansen cointegration test which verifies a long term cointegration relationship between the variables (the test results are reported in the appendices).

\section{3) Analysis of the estimation results}

The results of the estimations, after the treatment and validation of the model, are presented in Table 2 and Table 3. We recall that the exogenous variables retained in this study explain the endogenous variable up to $82.59 \%$ ( $22=82.59 \%$ ). The results of the estimation present a negative and significant coefficient of recall at the $5 \%$ level $(0.916 ;[-4.829])$, which confirms the existence of an adjustment relationship towards the long-term equilibrium. The model to be retained is D (HDI). The following Table 2 presents the adjustment speeds of the VECM equations.

In addition to the coefficient of the recall force, which is negative and significant, the results of the test of autocorrelation of the residuals by the correlogram of the residuals and the Ljung-Box statistics confirm the absence of autocorrelation of the residuals. Indeed, according to the results of the test, all the terms of the auto-correlation functions (simple and partial) are all located inside the

Table 2. Fitting speed of the VECM equations.

\begin{tabular}{ccc}
\hline Variable & Coefficient & $t$-student \\
\hline$D(H D I)$ & $-0.916^{* *}$ & {$[-4.829]$} \\
$D(\operatorname{InGDPC})$ & -2.008 & {$[-1.602]$} \\
$D($ InRENT $)$ & 6.925 & {$[0.541]$} \\
$D\left(U_{-} E M R\right)$ & $156.317^{* *}$ & {$[3.446]$} \\
$D(I M R)$ & 19.066 & {$[1.146]$} \\
\hline
\end{tabular}

Source: Authors, from Eviews 7. Notes: t-students are shown in square brackets. ${ }^{\star \star *} ;{ }^{\star *}$ and ${ }^{\star}$ represent significance at the $1 \%, 5 \%$ and $10 \%$ thresholds, respectively.

Table 3. Result of the long-term model estimation. Endogenous variable: HDI.

\begin{tabular}{ccc}
\hline Variable & Coefficient & $t$-student \\
\hline $\operatorname{In} G D P C(-1)$ & -0.074 & {$[-2.747]^{* *}$} \\
$\operatorname{In} R E N T(-1)$ & -0.0249 & {$[-4.746]^{* *}$} \\
$U_{-} E M R(-1)$ & -0.003 & {$[-9.116]^{\star *}$} \\
$\operatorname{IMR}(-1)$ & 0.002 & {$[13.636]^{* *}$} \\
\hline
\end{tabular}

Source: Authors, from Eviews 7. The t-students are in square brackets. 
confidence interval materialized by the lines significantly different from zero (associated probabilities are higher than 5\%) which leads to retain the hypothesis $H_{0}$ of no auto-correlation. The residual is white noise, so the results can be used for analysis.

Table 3 shows that in the long term: the GDPC, dependence on oil revenues and the unemployment rate have a significant and negative effect on development (HDI) in Congo. Indeed, a 1\% increase in the GDPC, all other things being equal, leads to a decrease in development (HDI) of $0.074 \%$. A one percent increase in dependence on oil revenues, all other things being equal, leads to a 0.0249 percent decrease in Congo's development. An increase of one unit in unemployment, all other things being equal, leads to a decrease in development (HDI) of 0.003 units. The infant mortality rate is positive and significant. An increase of one unit in infant mortality, all other things being equal, leads to an increase in development (HDI) of 0.0026 units.

The reading of Table 4 shows that in the short term: the dependence on the oil rent has a negative and significant effect on the development (HDI), the increase of $1 \%$ of the dependence on the oil rent, all things being equal, involves a decrease of the development of 0.0179 . The infant mortality rate is negative, an increase of one unit in infant mortality, all other things being equal, leads to a decrease in development of 0.0126 units. The GDPC is significant and negative on development. A one-unit increase in GDPC, all else equal, leads to a decrease in development of 0.0808 units. The unemployment rate is likely to have a negative influence on development in Congo.

\subsubsection{Interpretation of the Results}

The results obtained in this study show that in the short and long term, dependence on oil revenues has a negative effect on IHD. The main lesson to be drawn from this result is:

Table 4. Result of the short-term model estimation. Endogenous variable: HDI.

\begin{tabular}{ccc}
\hline Variables & Coefficient & t-student \\
\hline$D(H D I(-1))$ & 0.3089 & {$[1.770]^{\star * *}$} \\
$D(H D I(-2))$ & 0.1224 & {$[0.723]$} \\
$D(\operatorname{In} G D P C(-1))$ & -0.0808 & {$[-1.851]^{\star * *}$} \\
$D(\operatorname{In} G D P C(-2))$ & 0.0116 & {$[0.312]$} \\
$D(\operatorname{In} R E N T(-1))$ & -0.0179 & {$[-3.362]^{\star *}$} \\
$D(\operatorname{In} R E N T(-2))$ & -0.0109 & {$[-1.897]^{\star * *}$} \\
$D\left(U_{-} E M R(-1)\right)$ & -0.0008 & {$[-1.477]$} \\
$D\left(U_{-} E M R(-2)\right)$ & -0.0007 & {$[-1.502]$} \\
$D(I M R(-1))$ & -0.0126 & {$[-4.977]^{\star *}$} \\
$D(I M R(-2))$ & 0.0162 & {$[4.793]^{* *}$} \\
$C$ & 0.0042 & {$[2.598]^{* *}$} \\
\hline
\end{tabular}

Source: Authors, from Eviews 7. 


\section{Heavy dependence on oil revenues: a brake on development.}

In fact, the oil rent evolves in the opposite direction to the HDI, i.e. an increase in the oil rent (by one point), all other things being equal, leads to a significant decrease in the HDI (at the $1 \%$ threshold) of 0.0249 . This result confirms our initial hypothesis. However, it validates the work of Aoun (2006); Sala-i-martin and Subramanian (2004); Ross (2001) who argue that a high dependence of the GDPC on oil revenues has a negative impact on development. Thus, this result is explained by the resource curse theory that establishes a negative correlation between natural resource abundance and economic growth (Sachs \& Warner, 1995). This brings us closer to the "Dutch disease" theory, which reveals that the development of the natural resource sector is detrimental to the development of other sectors of the economy, mainly the industrial sector, because of the appreciation of the real exchange rate that it induces, considering that the slowdown of the industrial sector hampers long-term economic growth.

In contrast, Maloney $(2001,2002)$ argues that there is little evidence of the relative underperformance of resource-rich countries in the long run. He argues that historical analysis shows that natural resources, particularly oil, have often supported the economic development of several major powers. This econometric analysis confirms the consensus established by several authors on the failures of development policies in economies dependent on a natural resource. By considering the human development index (HDI) as a development indicator in the Congo, we argue that dependence on oil revenues is a brake on economic development.

\section{Conclusion}

The objective of this study was to analyze the effects of the oil rent on economic development in Congo over the period from 1987 to 2016. Following the estimation by the Vector Error Correction Method (VECM), through the analysis of stationarity, cointegration and the determination of the optimal number of lags, the oil rent has a negative and significant effect on development in Congo. The declines in growth and development in the Congo are mainly linked to an overdependence on oil rents, the deterioration of governance and the generalization of corruption. The hypothesis defended in this study has been verified. The negative effect of oil wealth on economic development and poverty in oil-producing countries has led to global awareness of the oil curse. The discovery and exploitation of oil resources is not a guarantee of development and growth. On the contrary, the experiences of African oil economies in general and of the Congo in particular prove that the oil rent is rather a curse.

The results of this study have allowed us to formulate an economic policy implication that focuses on the sustainable management of oil resources with future generations in mind and investing in the diversification of the country's economic activities. This would help eradicate poverty and improve the standard of living of the population. Without calling into question our results, this study 
did not take into account the institutional and governance problems that are linked to the opacity of the management of the oil sector, making it difficult to access data.

\section{Conflicts of Interest}

The authors declare no conflicts of interest regarding the publication of this paper.

\section{References}

Amin, S. (1973). Neocolonialism.

http://patrimoinenumeriqueafricain.com:8080/jspui/handle/123456789/2770

Aoun, M. C. (2006). Impact of Oil Rent on the Economies of Oil Exporting Countries. Doctoral Dissertation, Université Paris-Dauphine. France, Paris: Edocif.

Auty, R. M. (2001). The Political Economy of Resource Driven Growth. European Economic Review, 45, 839-846. https://doi.org/10.1016/S0014-2921(01)00126-X

Bhagwati, J. (1958). Immiserizing Growth: A Geometric Note. Review of Economic Studies, 25, 201-205. https://doi.org/10.2307/2295990

Carbonnier, G. (2007). How to Avert the Natural Resource Curse? Swiss Yearbook of Development Policy, 26, 83-98. https://doi.org/10.4000/aspd.123

Chevalier, J. N. (1975). Theoretical Elements of Introduction to the Economics of Oil: Analysis of the Balance of Power. Revue d'Economie Politique, 2, 230-256.

Davis, G. A. (1995). Learning to Love Dutch Disease: Evidence from the Mineral Economies. World Development, 23, 1765-1779.

https://doi.org/10.1016/0305-750X(95)00071-J

Doppelhofer, G., Sala-i-Martin, X., \& Miller, R. (2004). Determinants of Long-Term Growth: A Bayesian Averaging of Classical Estimates (BACE) Approach. American Economic Review, 94, 813-835. https://doi.org/10.1257/0002828042002570

Georgescu-Roegen, N. (1979). Energy and Matter in Mankind's Technological Circuit. Journal of Business Administration, 10, 107-127.

Global Witness (2017). Challenging Abuses of Power to Protect Human Rights and Secure the Future of Our Planet. https://www.globalwitness.org/en/

Gunder, A. F. (1970). Latin American: Underdevelopment or Revolution. http://digamo.free.fr/agfrank.pdf

Gylfason, T. (2001). Natural Resources and Economic Growth: What Is the Connection? Cesifo Working Paper No. 530, Munich: Institute for Economic Research.

Hirschman, A. O. (1958). The Strategy of Economic Development. Paris: Eds Ouvrières.

Hotelling, H. (1931). The Economics of Exhaustible Resources. The Journal of Political Economy, 39, 137-175. https://doi.org/10.1086/254195

Innis, H. A. (1967). The Importance of Staple Products. In: W. T. Easterbrook, \& M. H. Watkinseds (Eds.), Approach to Canadian Economic History (pp. 5-39). Toronto: Antioch Review Inc. (First published in 1930)

Leamer, E. E. (1984). Sources of Comparative Advantage: Theory and Evidence. Cambridge, MA: The MIT Press.

Lederman, D., \& Maloney, W. F. (2007). Neither Curse, nor Destiny: Introduction to Natural Resources and Development. Washington, DC: World Bank Press. 
Leontief, W. (1953). Domestic Production and Foreign Trade: The American Capital Position Reexamined. Proceedings of the American Philosophical Society, 97, 332-349.

Mackintosh, W. A. (1967). Economic Factors in Canadian Economic History. Canadian Historical Review, 4, 12-25. https://doi.org/10.3138/CHR-04-01-02

Maloney, W. F. (2001). Innovation and Growth in Resource Rich Countries. Working Paper No. 148, Santiago: Central Bank of Chile.

Maloney, W. F. (2002). Missed Opportunities: Innovation and Resource Based Growth in Latin America. Policy Research Working Paper Series No. 2935 World Bank. https://doi.org/10.1353/eco.2002.0019

Mouhoubi, A. (2011). La rente pétrolière repensée: Eléments d'une nouvelle perceptiond'un concept galvaud. Les Cahiers du CREAD, 96, 5-26.

Ngodi, E. (2005a). Afrique centrale: Crises économiques et mécanismes de survies. In D. P. Mukawa, \& G. Tchouassi (Eds.), Pétrole et géopolitique en Afrique centrale (pp. 75-104). Dakar, Senegal: Codesria.

Ngodi, E. (2005b). Gestion des ressources pétrolières et développement en Afrique. Présentation à la 11ème Assemblée générale du CODESRIA, Maputo.

Ohlin, B. (1933). Inter-Regional and International Trade. Cambridge, MA: Harvard University Press.

Ramey, D., \& Ramey, V. A. (1995). Cross Country Evidence on the Link between Volatility and Growth. American Economic Review, 85, 1138-1151. https://doi.org/10.3386/w4959

Ross, M. L. (2001). Does Oil Hinter Democracy. World Politics, 53, 325-361. https://doi.org/10.1353/wp.2001.0011

Sachs, J., \& Vial, J. (2001). The Latin America Competitiveness Report, 2001-2002. Cambridge, MA: Center for International Development and World Economic Forum.

Sachs, J., \& Warner, A. (1995). Natural Resource Abundance and Economic Growth. NBER Working Paper No. 5398. https://doi.org/10.3386/w5398

Sachs, J., \& Warner, A. (1997). Natural Resources and Economic Growth. Cambridge, MA (mimeo): HIID.

Sala-i-Martin, X., \& Subramanian, A. (2004). Addressing the Natural Resource Curse: An Illustration from Nigeria. NBER Working Paper No. 9804. https://doi.org/10.3386/w9804

Sid-Ahmed, A. (1989). Economics of Industrialization from Natural Resources. Geneva: Piblisud.

Solow, R. (1974). The Economics of Resources or the Resources of Economics. In C. Gopalakrishnan (Ed.), Classic Papers in Natural Resource Economics (pp. 257-276). London: Palgrave Macmillan. https://doi.org/10.1057/9780230523210_13

Stiglitz, J. (1974). Growth with Exhaustible Natural Resources: Efficient and Optimal Growth Paths. The Review of Economic Studies, 41, 123-137. https://doi.org/10.2307/2296377

UNDP (2012). Study on the Vulnerability of the Congolese Economy and Its Diversification Prospects. Brazzavile: UNDP Press.

United Nations Development Programme (UNDP) (2015). Contribution to the 2015 United Nations Economic and Social Council (ECOSOC) Integration Segment. https://www.un.org/en/ecosoc/integration/2015/pdf/undp.pdf

van der Ploeg, F. (2011). Natural Resources: Curse or Blessing? Journal of Economic Li- 
terature, 49, 366-420. https://doi.org/10.1257/jel.49.2.366

Watkins, M. (1963). A Staple Theory of Economic Growth. Canadian Journal of Economics and Political Science, 29, 141-158. https://doi.org/10.2307/139461

World Bank (2015). Economic and Financial Situation Monitoring Report. Washington DC: World Bank Press.

Wright, G., \& Czelusta, J. (2004). The Myth of the Resource Curse. Challenge, 47, 6-38. https://doi.org/10.1080/05775132.2004.11034243 


\section{Appendices}

Table A1. Results of the stationarity tests.

\begin{tabular}{|c|c|c|c|c|c|c|c|}
\hline Variables & $\begin{array}{l}\text { Type } \\
\text { of test }\end{array}$ & $\begin{array}{l}\text { With constant } \\
\text { and without } \\
\text { trend }\end{array}$ & $\begin{array}{l}\text { With } \\
\text { constant } \\
\text { and trend }\end{array}$ & $\begin{array}{c}\text { Without } \\
\text { constant and } \\
\text { without trend }\end{array}$ & $\begin{array}{l}\text { Critical } \\
\text { values } \\
\text { at } 5 \% .\end{array}$ & Test stat & Decisions \\
\hline \multirow{3}{*}{ HDI } & $\mathrm{ADF}$ & Yes & No & No & -2.991878 & -3.072932 & $\mathrm{I}(0)$ \\
\hline & PP & No & Yes & No & -3.580623 & -5.167402 & I (1) \\
\hline & KPSS & No & Yes & No & 0.146000 & 0.188574 & $\mathrm{I}(0)$ \\
\hline \multirow{3}{*}{ RENT } & $\mathrm{ADF}$ & Yes & No & No & -2.967767 & -3.569115 & I (0) \\
\hline & PP & Yes & No & No & -2.967767 & -3.463051 & $\mathrm{I}(0)$ \\
\hline & KPSS & Yes & No & No & 0.463000 & 0.379000 & $\mathrm{I}(0)$ \\
\hline \multirow{3}{*}{ U_EMR } & $\mathrm{ADF}$ & No & No & Yes & -2.971853 & -7.077170 & I (1) \\
\hline & PP & No & No & Yes & -1.953381 & -8.754585 & I (1) \\
\hline & KPSS & No & Yes & No & 0.146000 & 0.101537 & $\mathrm{I}(0)$ \\
\hline \multirow{3}{*}{ GDPC } & $\mathrm{ADF}$ & No & No & Yes & -1.953381 & -4.749153 & I (1) \\
\hline & PP & No & No & Yes & -1.953381 & -4.749918 & I (1) \\
\hline & KPSS & Yes & No & No & 0.463000 & 0.316018 & $\mathrm{I}(0)$ \\
\hline \multirow{3}{*}{ IMR } & $\mathrm{ADF}$ & No & Yes & No & -3.580623 & -7.348432 & I $(0)$ \\
\hline & PP & No & No & No & -1.953858 & -0.271532 & I (2) \\
\hline & KPSS & Yes & No & No & 0.463000 & 0.443922 & $\mathrm{I}(0)$ \\
\hline
\end{tabular}

Table A2. Results of the cointegration tests.

\begin{tabular}{cccccc}
\hline Data Trend: & None & None & Linear & Linear & Quadratic \\
\hline Test Type & $\begin{array}{c}\text { No Intercept } \\
\text { No Trend }\end{array}$ & $\begin{array}{c}\text { Intercept } \\
\text { No Trend }\end{array}$ & $\begin{array}{c}\text { Intercept } \\
\text { No Trend }\end{array}$ & $\begin{array}{c}\text { Intercept } \\
\text { Trend }\end{array}$ & $\begin{array}{c}\text { Intercept } \\
\text { Trend }\end{array}$ \\
\hline Trace & 3 & 4 & 5 & 4 & 5 \\
Max-Eig & 2 & 2 & 2 & 2 & 2 \\
\hline
\end{tabular}

Table A3. Determination of the optimal number of delays.

\begin{tabular}{ccccccc}
\hline Lag & LogL & LR & FPE & AIC & SC & HQ \\
\hline 0 & -21.36784 & NA & $4.53 \mathrm{e}-06$ & 1.883417 & 2.121311 & 1.956143 \\
1 & 71.48256 & 145.9078 & $3.68 \mathrm{e}-08$ & -2.963040 & -1.535678 & -2.526681 \\
2 & 146.4298 & $91.00733^{\star}$ & $1.25 \mathrm{e}-09^{*}$ & $-6.530699^{*}$ & $-3.913868^{\star}$ & $-5.730707^{\star}$
\end{tabular}

Indicates the order selected by the criterion; LR: sequential modified LR test statistic (each test at $5 \%$ level); FPE: Final predictionerror; AIC: Akaike information criterion; SC: Schwarz information criterion; HQ: Hannan-Quinn information criterion.

Table A4. Result of the error autocorrelation test.

\begin{tabular}{ccccccc}
\hline Autocorrelation & Partial Correlation & & AC & PAC & Q-Stat & Prob \\
\hline$\cdot|\cdot|$ & $\cdot|\cdot|$ & 1 & 0.003 & 0.003 & 0.0003 & 0.986 \\
\hline
\end{tabular}




\section{Continued}

\begin{tabular}{|c|c|c|c|c|c|c|}
\hline.$||$. &.$|\cdot|$ & 2 & 0.005 & 0.005 & 0.0012 & 0.999 \\
\hline.${ }^{*}||$. &.${ }^{*}||$. & 3 & -0.151 & -0.151 & 0.7452 & 0.863 \\
\hline$*^{* *}||$. &.$^{* *}||$. & 4 & -0.214 & -0.217 & 2.2971 & 0.681 \\
\hline.${ }^{*} .1$ &.$* *||$. & 5 & -0.188 & -0.206 & 3.5537 & 0.615 \\
\hline.$* *||$. & $* * *||$. & 6 & -0.277 & -0.354 & 6.4066 & 0.379 \\
\hline$\left.\cdot\right|^{*} \cdot \mid$ &.$||$. & 7 & 0.108 & -0.035 & 6.8672 & 0.443 \\
\hline$\left.\cdot\right|^{* *} \cdot \mid$ & $.1^{*} \cdot 1$ & 8 & 0.242 & 0.135 & 9.2899 & 0.318 \\
\hline $.1^{*} \cdot 1$ &.$|\cdot|$ & 9 & 0.133 & -0.010 & 10.055 & 0.346 \\
\hline.$||$. & ${ }^{*}||$. & 10 & -0.029 & -0.193 & 10.094 & 0.432 \\
\hline $.1^{*} \cdot 1$ &.$|\cdot|$ & 11 & 0.092 & 0.046 & 10.510 & 0.485 \\
\hline$\cdot{ }^{*}||$. &.$|\cdot|$ & 12 & -0.067 & -0.035 & 10.744 & 0.551 \\
\hline
\end{tabular}

